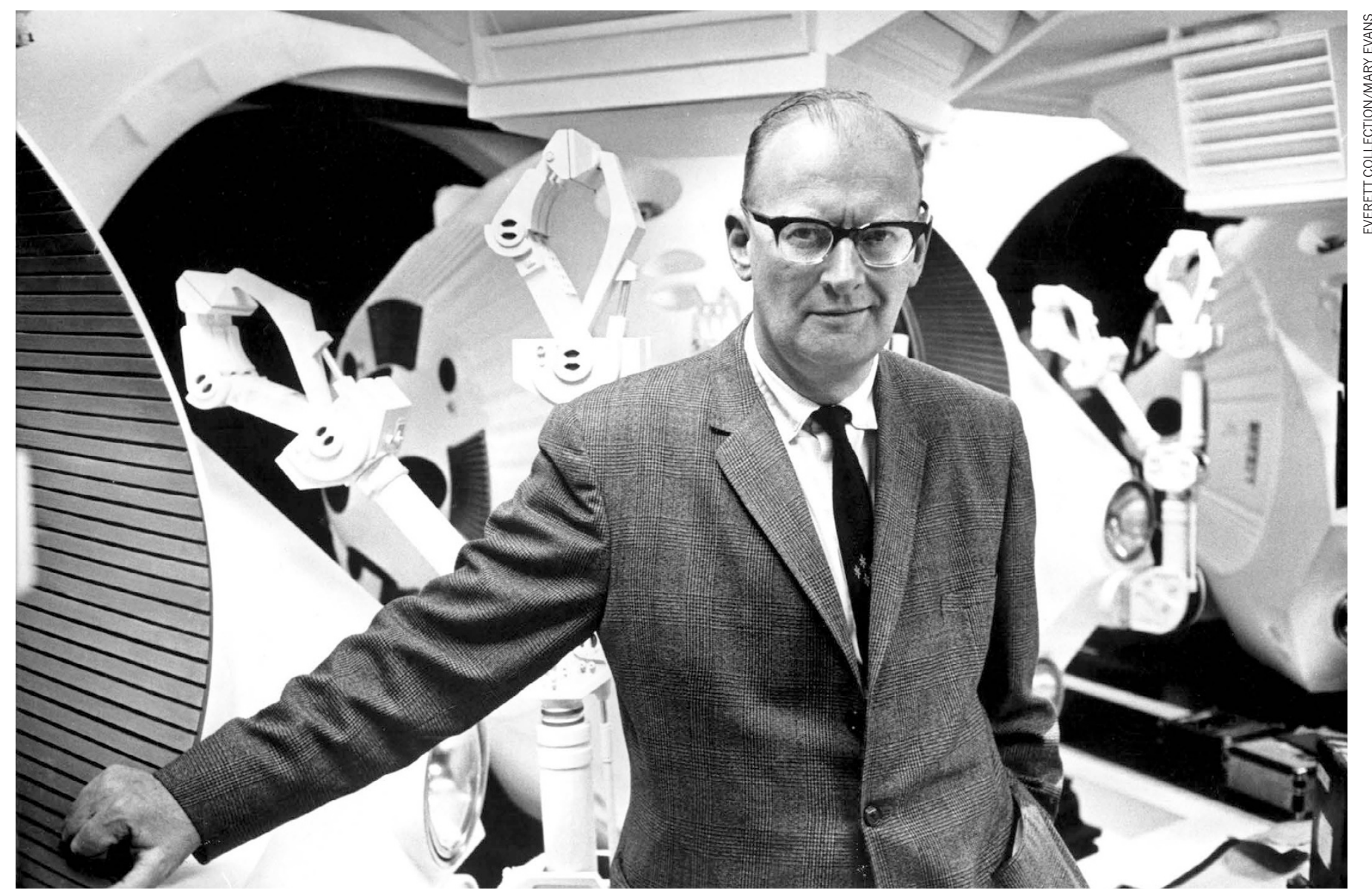

Arthur C. Clarke in 1968, on the set of 2001: A Space Odyssey.

\title{
He wrote the future
}

\section{On Arthur C. Clarke's centenary, Andrew Robinson lauds a prescient, original writer.}

$\mathrm{W}$

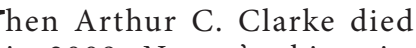
in 2008, Nature's obituarist - astrophysicist and sciencefiction writer Gregory Benford - hailed him as "the most famous of science-fiction writers" (G. Benford Nature 452, 546; 2008). The makers of Hollywood biopic Steve Jobs (2015) seem to agree: the film opens with black-and-white footage of Clarke from a television interview filmed in 1974, two years before Jobs co-founded Apple Computer. Balding and bespectacled, Clarke stands opposite the interviewer and his young son in a large office thrumming with massive computers. He captivates them and us when he says: "The big difference when he grows up - in fact you won't have to wait for the year 2001 - is that he will have in his own house ... a console through which he can talk to his friendly local computer and get all the information he needs for his everyday life."

Clarke, who was born 100 years ago, was famously prescient. He anticipated, for instance, satellite communications and powerful computers in the form of HAL in the cult film 2001: A Space Odyssey (1968). He also popularized the 'space elevator'. That concept, which now has some solid scientific support (see Nature http://doi. org/fv4rxv; 2007),

was central to

The Fountains of

Paradise (1979),

one of his score

of science-fiction novels.

As an editor of Clarke's non-

"I was struck by his unquenchable curiosity about science, literature and civilization

- human and fiction in his extraterrestrial." eighties, I was struck by his unquenchable curiosity about science, literature and civilization - human and extraterrestrial. He would usually agree to my request for a book review after an initially discouraging response on grounds of frantic busyness. The result seldom needed any editing.

Clarke's interest in telecommunications began in rural Somerset, UK. His father had been an engineer in charge of telephone and telegraph circuits; his mother, a telegraph operator. The young Arthur received castoff equipment, such as telephones, switchgear and a photocell from his relative George Grimstone, an engineer who taught him to build wireless crystal sets. Clarke also experimented with homemade rockets on family farmland. He read David Lasser's introduction to rocketry and space flight, The Conquest of Space (1931); devoured US science-fiction pulp magazines; and joined the British Interplanetary Society, founded in 1933 to promote space flight (then seen as a concept of the lunatic fringe by most scientists and engineers).

In 1936, having scored $100 \%$ for arithmetic in the civil-service entrance examination, 
Clarke moved to London and worked for the Exchequer and Audit Department. During the Second World War, he gained experience in electronic engineering while building and testing ground-controlled radar in the Royal Air Force - later dramatized in his sole nonscience-fiction novel, Glide Path (1963).

In 1945, Clarke inadvertently launched a career as a futurologist with his outline for a geostationary communications satellite. In a letter ('V2 for ionosphere research?') published in February's issue of Wireless World and inspired by the German V2 rockets then landing on London, he made a revolutionary proposal:

An 'artificial satellite' at the correct distance from the earth would make one revolution every 24 hours; i.e., it would remain stationary above the same spot and would be within optical range of nearly half the earth's surface. Three repeater stations, 120 degrees apart in the correct orbit, could give television and microwave coverage to the entire planet.

Clarke realistically concluded: "I'm afraid this isn't going to be of the slightest use to our postwar planners, but I think it is the ultimate solution to the problem." He followed up with a more detailed piece in Wireless World that October, envisioning "spacestations" that relied on thermionic valves serviced by an onboard crew supplied by atomic-powered rockets.

\section{SPACE GODFATHER}

The first commercial communications satellite, Telstar I, was built by Bell Telephone Laboratories and launched in 1962. The first to be geostationary, the Hughes Aircraft Company's Intelsat I ('Early Bird'), went up in 1965. Both launched on conventional rockets, and operated with transistors and without human maintenance. The two US engineers chiefly responsible John Pierce for Telstar and Harold Rosen for Intelsat - saw Clarke as the father of satellite communications. Richard Colino, director-general of Intelsat (the International Telecommunications Satellite Organization) agreed in his foreword to a collection of Clarke's technical writings, Ascent to Orbit (1984). Clarke preferred "godfather", noting with uncharacteristic modesty in the book that he had received "rather more of the credit, I suspect, than I really deserve". In old age, however, he told me that his comsat article was "the most important thing I ever wrote".

Clarke consolidated his wartime hands-on training with a degree in mathematics and physics at King's College London, graduating in 1948. In 1950 he published the nonfiction book Interplanetary Flight, which he claimed was the first English-language study offering "the basic theory of space travel

\section{Books in brief}

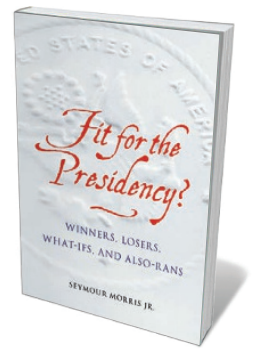

Fit for the Presidency?: Winners, Losers, What-Ifs, and Also-Rans Seymour Morris Jr РОтОМАC (2017)

Former pollster Seymour Morris Jr runs a political-science thought experiment by scrutinizing the curricula vitae of 15 US presidential hopefuls from 1789 to 1980 . 'Shoo-in' DeWitt Clinton, a naturalist and statesman, lost to James Madison in 1812. Abraham Lincoln looked unqualified, yet unusual work experience (including navigating the treacherous Mississippi River) endowed him with the pragmatism needed to win the American Civil War. Morris reminds that sterling qualities make good presidents, but they must be the right qualities - and voters must be capable of recognizing them.

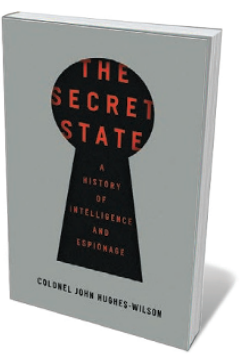

The Secret State: A History of Intelligence and Espionage

John Hughes-Wilson PEGASUS (2017)

From the cursus publicus (imperial communications network) of ancient Rome to cybersurveillance, espionage is as old as war. In this sweeping history, John Hughes-Wilson anatomizes the intelligence process and the evolution of covert methodologies and technologies that maintain (or disrupt) geopolitical balance. Nineteenth-century German spymaster Wilhelm Stieber, for instance, sparked the paranoia that led in part to the First World War. Hughes-Wilson also masterfully summarizes the workings of terrorism and cyberwar. A deft tour of the shadow side of 'speaking truth to power'.

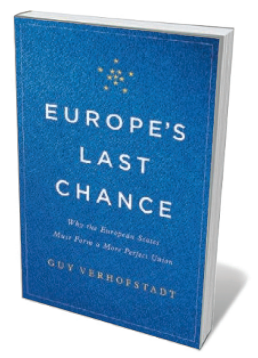

\section{Europe's Last Chance}

Guy Verhofstadt BASIC (2017)

Terrorist attacks, tangled economics, tsunamis of refugees - the European Union faces a perfect storm, with added turbulence from nationalism. Here, Guy Verhofstadt — leader of the European Parliament's liberal faction - argues that the political solution is a US-style federation of member states. He offers an insider's view, not least of prevailing issues such as Europe's toothless responses to Middle Eastern conflict and Russian belligerence. His hypothetical "United States of Europe", predicated on early efforts towards an EU, is both hugely ambitious and highly plausible.

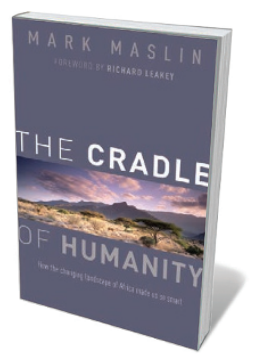

\section{The Cradle of Humanity}

Mark Maslin OXFORD UNIVERSITY PRESS (2017)

Palaeoclimatologist Mark Maslin delves into deep time to trace humanity's rise to geological hegemony. Examining early hominin finds in East Africa, he spotlights three stages (bipedalism in Australophithecus, a jump in brain size in Homo erectus and Homo sapiens' arrival some 195,000 years ago) and the roles of climate change, celestial mechanics and plate tectonics in their emergence. Ultimately, he theorizes that 'climate pulses' in the Rift Valley, in which hyper-arid conditions alternated with the formation of vast lakes, helped to drive the evolution of the big hominin brain.

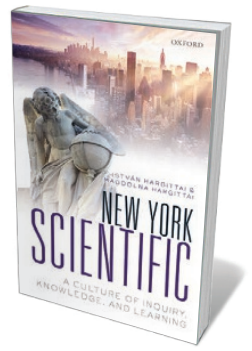

New York Scientific: A Culture of Inquiry, Knowledge, and Learning Istvan Hargittai and Magdolna Hargittai OXFORD UNIVERSITY PRESS (2016) New York may blaze with neon, but many of the city's byways shine with scientific brilliance - if you know where to look. Chemists Istvan Hargittai and Magdolna Hargittai map the territory for this quirkily comprehensive guide to key landmarks and institutions. There are scores here, from the Nobel obelisk to gems of the city's "biotechnology corridor" (such as the Rockefeller University, where Oswald Avery isolated DNA), the home of African American inventor Lewis Latimer and monuments galore. Barbara Kiser 


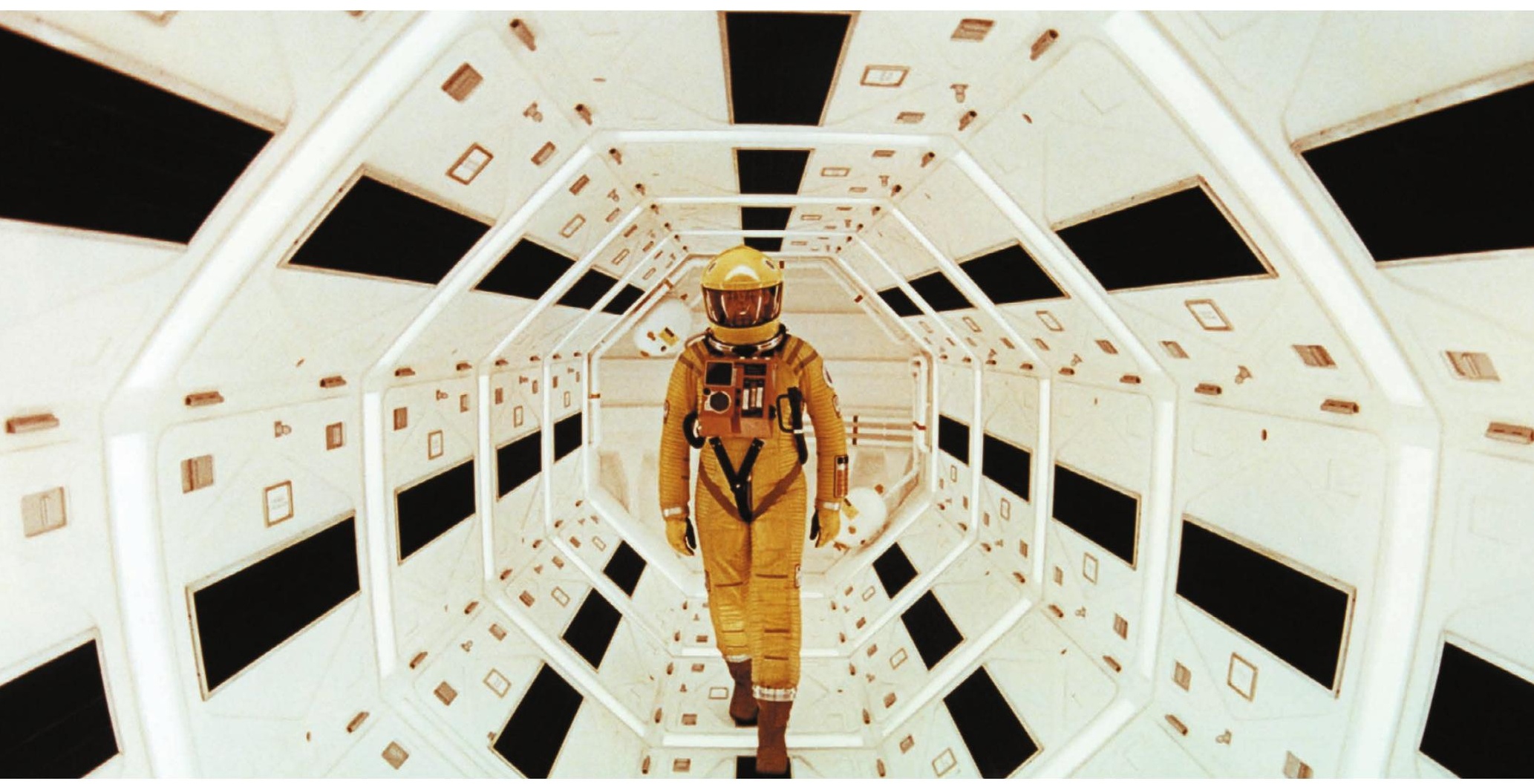

Gary Lockwood as Frank Poole in 2001.

in any technical detail". (It borrowed from Hermann Oberth's The Rocket into Planetary Space, published in German in 1923.) The cold-war threat of nuclear war might have contributed to Clarke's growing enthusiasm for humanity's future beyond Earth. After 1957, when the Soviet Union's Sputnik ushered in the space age, Clarke excelled at communicating this optimism to scientists, engineers and the public through writings, television series, media interviews and his fraught collaboration with Stanley Kubrick as co-screenwriter of 2001.

\section{VISION AND INFLUENCE}

Clarke's prolific fiction encompasses the grittily technical and the unashamedly fantastic, sometimes almost on the same page. His numerous short stories include 'The Sentinel' (1951), which contains a key element of 2001 - the human discovery of an alien artefact on the Moon - and 'The Nine Billion Names of God' (1953), an ironic tale of two computer engineers hired by Tibetan monks to generate the divine monikers.

His best-known novel, apart from 2001 (Clarke and Kubrick developed the 1968 book alongside the film), is the semimystical Childhood's End (1953). Here Earth is controlled by the Overlords, benevolent aliens who have abolished war, hunger and disease, along with adventure and innovation. As well as the elevator, the technodrama The Fountains of Paradise features an

island closely resembling Clarke's adopted home, Sri Lanka. The Songs of Distant Earth (1986), his own favourite novel, is set among former Earthlings who have escaped the predicted destruction of the planet by a solar nova in the fourth millennium, to settle on Thalassa, an oceanic planet in another star system.

His copious non-fiction comprised articles and reviews collected in Greetings, Carbon-Based Bipeds! (1999), as well as several influential books about space. Astronomer and science popularizer Carl Sagan recalled Interplanetary Flight as "a turning point in my scientific development".

"We have to clean up the gutters in which we are now walling but we must not lose sight of the stars."

\section{NASA rocket}

designer Wernher von Braun used The Exploration of Space (1951) to convince US President John F. Kennedy that Americans should and could go to the Moon. Profiles of the Future (1962), with its chapter on teleportation, inspired Gene Roddenberry to create Star Trek's futuristic advances (S. Perkowitz Nature 537, 165-166; 2016).

Throughout, Clarke's futurology was enhanced by an awareness of the history of civilization, science and technology. Profiles, for example, remarks that writing is "perhaps the most important single invention of mankind". Add to this his perceptive forecasts of technological developments in space including his own satellite-linked broadcasts from Sri Lanka - and you have the basis of his unique reputation.

Will it endure, as the man himself recedes into history? The answer depends on future developments in space. Will humanity colonize the Moon, Mars and beyond? Clarke (for whom asteroid 4923 is named) believed that we must. In 1992, giving his own twist to a famous remark by Oscar Wilde, Clarke wrote in The Bulletin of the Atomic Scientists: "We have to clean up the gutters in which we are now walking - but we must not lose sight of the stars."

And what of the prospect of extraterrestrial contact? At the end of 2000, Clarke scribbled with characteristic brio in my copy of Greetings, Carbon-Based Bipeds!, "I hope this greeting comes in my lifetime!" On his 90th birthday in 2007, his last wish was for "ETs to call us", perhaps by means of a radio signal or even an astronomical phenomenon. The best of his imaginative, witty and scientifically grounded writings will surely help to keep this ultimate of riddles at the forefront of human consciousness.

Andrew Robinson was Arthur C. Clarke's editor at The Times Higher Education Supplement from 1994 to 2005. His most recent book is Earth-Shattering Events: Earthquakes, Nations and Civilization. e-mail:andrew@andrew-robinson.org 